\title{
SEASONAL VARIATION OF HEPATITIS A VIRUS INFECTION IN THE CITY OF RIO DE JANEIRO, BRAZIL
}

\author{
Livia Melo VILLAR, Vanessa Salete DE PAULA \& Ana Maria Coimbra GASPAR
}

\begin{abstract}
SUMMARY
Hepatitis A virus (HAV) infection constitutes a major public health problem in Brazil. The transmission of HAV is primarily by fecal-oral route so the water is an important vehicle of HAV dissemination. There is a great incidence of acute cases of hepatitis A in some areas of Brazil however the seasonal variation of these cases was not documented. The aim of this study was to determine the seasonality of HAV infection in Rio de Janeiro. From January 1999 to December 2001, 1731 blood samples were collected at the National Reference Center for Hepatitis Viruses in Brazil (NRCHV). These samples were tested by a commercial enzyme-immunoassay to detect anti-HAV IgM antibodies. Yearly positive rates were $33.74 \%$ in 1999, 32.19\% in 2000, and 30.63\% in 2001. A seasonal variation was recognized with the highest incidence in spring and summer. Furthermore a seasonal increase in incidence of HAV infection was found during the rainy season (December to March) because the index of rains is very high. It is concluded that HAV infections occur all year round with a peak during hot seasons with great number of rains.
\end{abstract}

KEYWORDS: Hepatitis A; Seasonal variation; Rio de Janeiro.

\section{INTRODUCTION}

Hepatitis A virus (HAV) is the principal etiological agent of hepatitis throughout the world, causing great morbidity in developed and undeveloped countries ${ }^{8}$. Over recent decades, the epidemiology of hepatitis A has changed in Brazil: the age of infection has been shifting towards older ages groups. This new epidemiological pattern reflects the improvement made in environmental hygiene, sewage disposal and the quality of drinking water in some areas of our country ${ }^{17}$. This situation creates a paradox because the number of susceptible persons has been increasing but the virus was not eliminated from the ambient.

HAV is an extremely stable virus commonly transmitted by fecaloral route, either directly from person to person or by contaminated food or water. HAV can survive for 12 weeks to 10 months in water ${ }^{2,10,14}$. This stability accounts for the frequent occurrence of waterborne and shellfish-transmitted outbreaks ${ }^{9,18}$. In this regard, the virus is relatively resistant to heat or chemical inactivation and this situation allows the dissemination of HAV infection.

Several investigators have reported the increase of enteric diseases according to the season ${ }^{3,4,11,13}$. This increase was due to resistance of enterovirus in the environment and the habits of the population studied. However, FATHALLA et $a l .{ }^{5}$ and PAPAEVANGELOU et $a l .{ }^{12} \mathrm{did}$ not observed the seasonal variation in the prevalence of hepatitis A in Saudi Arabia and Greece, respectively.
This study was carried out to investigate any seasonal variation in the occurrence of acute cases of hepatitis A in the city of Rio de Janeiro, Brazil.

\section{MATERIAL AND METHODS}

Study area - Rio de Janeiro is a large urban center of Brazil and is composed of a Center and a periphery. The temperature is high all year ranging from $30^{\circ} \mathrm{C}$ to $40^{\circ} \mathrm{C}$. The study was carried out at the National Reference Center for Hepatitis Viruses (NRCHV), Oswaldo Cruz Foundation, Rio de Janeiro, Brazil during January 1999 to December 2001.

Study population - The population was composed from 1731 subjects who were referred to NRCHV by all the physicians in our state. The NRCHV is a center for diagnosis of viral hepatitis in Rio de Janeiro so most of the cases of hepatitis are referred to this entity to investigate the etiological agent of infection. In this study, all samples belong to sporadic cases and outbreaks were excluded. The sera samples were obtained from persons with ages ranging between 0 to 84 years in the three years. Formal consent to participate was obtained from each individual.

Laboratory tests and statistical analysis - All sera were obtained by clotting and centrifugation at room temperature; sera were frozen and stored at $-20{ }^{\circ} \mathrm{C}$ until assayed. Anti-HAV IgM antibodies were

This study was supported by CNPq.

Departament of Virology, Oswaldo Cruz Institute/FIOCRUZ, Av. Brasil 4365, 21045-900 Rio de Janeiro, RJ, Brasil.

Correspondence to: Livia Melo Villar, Fax: +55-21-2270.6397. E-mail: 1villar@ioc.fiocruz.br 
determined using a commercial enzyme immune-assay kit (Organon Teknika, Hepanostika).

Seasonal variability was determined by evaluation of monthly prevalence, calendar seasons (winter, spring, summer, fall), and rainy versus dry seasons. Statistical analyses were carried out using the Epi INFO 6.01 software $^{6}$. Probability was determined by chi-squared tests using Yates correction. Differences were regarded as significant when $\mathrm{p} \leq 0.05$.

\section{RESULTS}

Overall, $32.06 \%$ of serum samples were positive for anti-HAV IgM. Yearly positive rates were as follows: $164(33.74 \%)$ of 486 in 1999, 198 (32.19\%) of 615 in 2000, and 193 (30.63\%) of 630 in 2001 (Fig. 1). When assessed by month of specimen collection, positivity rates ranged from $20.68 \%$ to $46.66 \%$ in year one, $10 \%-45.31 \%$ in year two, and $15.11 \%$ to $45.65 \%$ in year three.

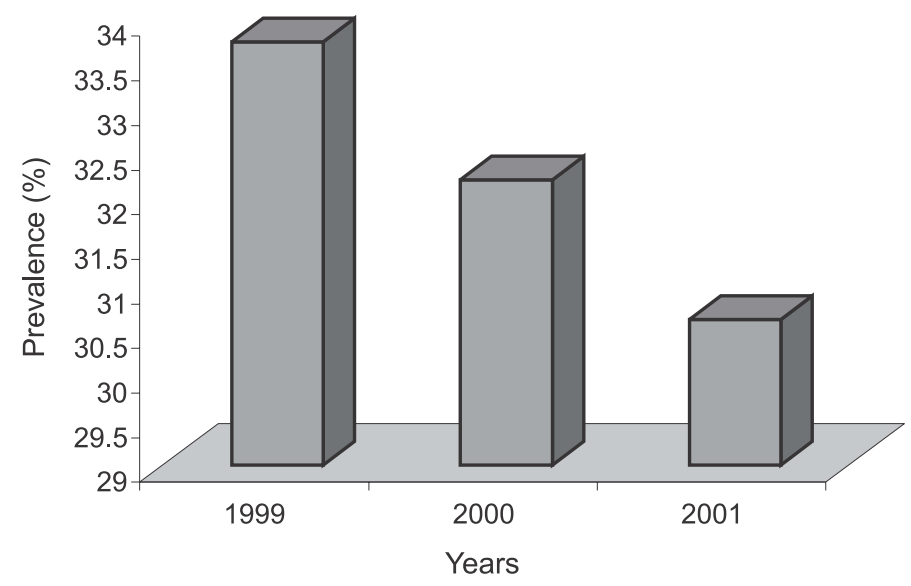

Fig. 1 - Prevalence of IgM anti-hepatitis A virus antibodies by year during study period in the population of Rio de Janeiro, Brazil.

To assess potential seasonal variability in the proportion of serum specimens positive for hepatitis A, three seasonal variables were constructed.

1) Month. Serum specimens were categorized according to the calendar month of their testing. Mean positivity rates for each of the 36 months comprising the study period were computed separately. To assess the statistical significance of the differences in positivity rates between the 12 calendar-years months, we combined the total number of specimens listed and the total number of positive specimens for each month across each of the three study years. Overall positivity rates for serum specimens ranged from a low of $16.56 \%$ (June) to a high of $41.48 \%$ (January) (Fig. 2). Statistical analyses indicated that monthly positivity rates varied considerably over time showing statistical significance $\left(\chi^{2}=48.79, \mathrm{df}=11, \mathrm{p}=0.000008\right)$.

2) Calendar season. Differences in serum positivity rates were analyzed according to the season of the calendar year. Data for December, January, February comprised the summer season; data for March, April, and May the fall season; June, July, and August the winter

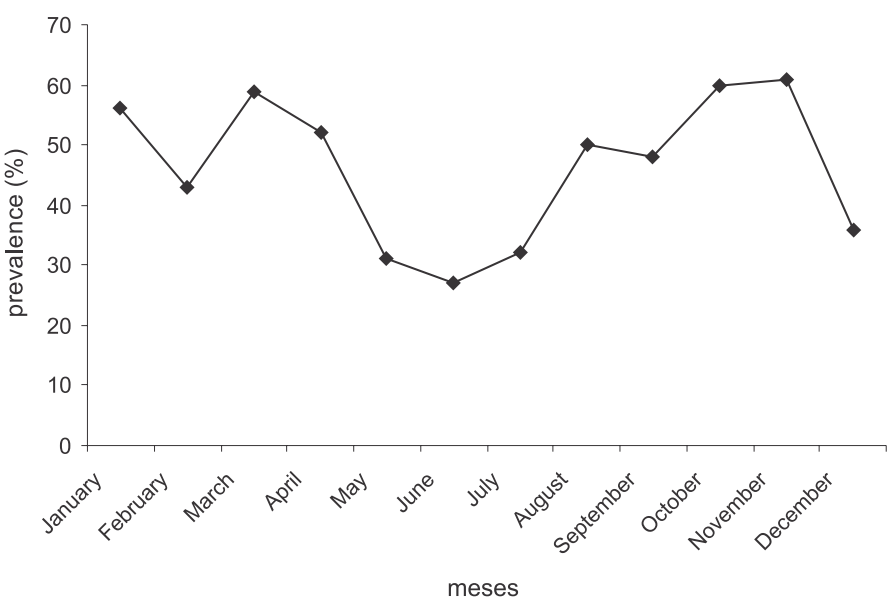

Fig. 2 - Prevalence of IgM anti-hepatitis A virus antibodies according to months of the year in the study period. (Mean precipitation index: rainy season: $193.06 \mathrm{~mm}$ versus dry season: $53.73 \mathrm{~mm})$.

season; and September, October and November the spring season. When assessed by season, overall positivity rates for specimens differed significantly. The lowest positivity rate occurred in the winter months $(24.0 \%)$, while the highest positivity rate occurred in the spring months $(37.55 \%)$ as it was demonstrated in Table 1 . The statistical analysis showed that positivity rates differ significantly between seasons in the study period $\left(\chi^{2}=24.39, \mathrm{df}=3, \mathrm{p}=0.000020\right)$.

3) Rainy versus dry season. Analysis of the data was performed dividing each of the three years into rainy and dry seasons. In general, rainfall in Rio de Janeiro occurs between the months November and March, with the other months falling into the dry season. In this three-year study period, the highest proportion of positive sera was detected during the rainy season, with $37.5 \%$ of specimens positive for anti-HAV IgM during this period. In contrast, the mean positivity rate for the remaining dry months was $28.54 \%$ (Table 1 ). The differences between these two proportions was statistically significant $\left(\chi^{2}=14.79, \mathrm{df}=1, \mathrm{p}=0.0001\right)$.

\section{Table 1}

Incidence of acute cases of hepatitis A virus infection in the study population according to the seasons

\begin{tabular}{lcccc}
\hline & \multicolumn{2}{c}{ Anti-HAV IgM } & & \\
\cline { 2 - 3 } & $\begin{array}{c}\text { Positive } \\
\mathrm{n}(\%)\end{array}$ & $\begin{array}{c}\text { Negative } \\
\mathrm{n}(\%)\end{array}$ & $\chi^{2}$ & $\mathrm{P}$ \\
\hline Total & $555(32.06)$ & $1176(67.93)$ & & \\
Calendar seasons & & & & \\
Summer & $135(37.08)$ & $229(62.91)$ & & \\
Fall & $142(30.66)$ & $321(69.33)$ & 24.39 & 0.000020 \\
Winter & $109(24.00)$ & $345(75.99)$ & & \\
Spring & $169(37.55)$ & $281(62.44)$ & & \\
Seasons & & & & \\
Rainy & $255(37.50)$ & $425(62.50)$ & 14.79 & 0.0001 \\
Dry & $300(28.54)$ & $751(71.45)$ & & \\
\hline
\end{tabular}


A chi-square test for linear trend was performed to assess whether yearly prevalence rates had significantly changed over the course of the study period. The result indicated a trend for less frequent IgM antibodies anti-HAV positive serum specimens over time however it was not statistically significant $\left(\chi^{2}=1.23, \mathrm{df}=2, \mathrm{p}=0.541\right)$.

\section{DISCUSSION}

Hepatitis A virus infection still poses an important public health problem in Brazil. HAV was responsible for more than $60 \%$ of the acute cases of hepatitis diagnosed at $\mathrm{NRCHV}^{7}$ but the real incidence of infection is underestimated because of underreporting and asymptomatic cases that are very common in children and adolescents. Most of suspected cases of hepatitis are diagnosed by the NRCHV who provides epidemiological data of this infection. During the three-year study, 1731 serum samples were tested at NRCHV to determine the etiological agent of hepatitis. The overall incidence of anti-HAV IgM was 32.06\% showing a great incidence of acute cases of hepatitis $A$ in this population. However the incidence of anti-HAV IgM decreases over time indicating that the number of susceptible persons are increasing. This pattern is common in developing countries, such as Brazil in which hygiene and sanitation have improved over the years with an increased proportion of infections occurring later in the adolescence or early adult life ${ }^{1,15,16}$. This new pattern demonstrates that adolescents and young adults are susceptible to HAV infection due to improvements in general standards of sanitation.

In this study, it was observed a peak incidence of HAV infection in our environment during the rainy season. It was observed that HAV infection in Rio de Janeiro occurred throughout the year. However most of the acute cases occurred during this season (37.50\%) and only $28.54 \%$ were reported in dry season. During the three years, the mean precipitation index in the rainy season was $193.06 \mathrm{~mm}$ versus 53.73 during dry season in our state. These data probably indicate that the HAV infections were due rainfall principally because these rains usually fill up the rivers so they could overflow and the persons could be contaminated with these waters. Other possible explanation is the swim habits of the population studied. All of them usually frequented the beaches of the Rio de Janeiro. The coast of Rio de Janeiro is very large and the city has a lot of rivers and waterfalls. Persons that lived at Rio de Janeiro usually swim at the beaches and rivers of the city. During the rainy season, the heavy runoff could cause contamination of these waters leading to excess of HAV infection during this season.

The seasonal variation of enteric diseases was previously demonstrated by several researches that reported a great incidence of these diseases principally in summer ${ }^{3,4}$, as it was documented in this study. In our report it was observed a great prevalence during hot months, spring and summer seasons. Furthermore we observed that the infection is more prominent in January and less common in June. These findings support the hypothesis that HAV infection occurs principally in hot months with the highest index of rains. Probably this seasonal variation depends on the climate, culture and geography of the region studied. HAV is very stable and could persist for a long time in environmental waters, so the swim habits of the population could disseminate HAV infection. In summary, this study demonstrated the presence of seasonal variation in the occurrence of HAV infection in a tropical environment. In this situation, the Government should invest in health education programs during this season to prevent $\mathrm{HAV}$ infection in the city of Rio de Janeiro.

\section{RESUMO}

\section{Variação sazonal da infecção pelo vírus da hepatite A no Rio de Janeiro, Brasil}

A infecção pelo vírus da hepatite A constitui um dos maiores problemas de saúde pública no Brasil. A transmissão do HAV ocorre principalmente pela via orofecal deste modo a água é um importante veículo da disseminação do HAV. Existe uma alta incidência de casos agudos de hepatite $\mathrm{A}$ em algumas áreas do Brasil entretanto a variação sazonal destes casos não foi relatada. O objetivo deste estudo foi avaliar a sazonalidade da infecção pelo HAV no Rio de Janeiro. De janeiro de 1999 a dezembro de 2001, 1731 amostras de sangue foram coletadas no Centro Nacional de Referência para Hepatites Virais no Brasil (CRNHV). Estas amostras foram testadas por um ensaio imunoenzimático comercial para detectar anticorpos IgM anti-HAV. Taxas de positividade anuais foram de 33,74\% em 1999, 32,19\% em 2000, e 30,63\% em 2001. Uma variação sazonal foi observada com um alto índice na primavera e verão. Também foi observado um aumento sazonal na incidência da infecção pelo HAV durante a estação chuvosa (Dezembro a Março) pois o índice de chuvas é muito alto. Foi concluído que a infecção pelo HAV ocorre o ano todo com um pico durante estações quentes com grande número de chuvas.

\section{ACKNOWLEDGMENTS}

The authors wish to thank to the NRCHV for the helpful assistance in the collecting of the samples.

\section{REFERENCES}

1.BARZAGA, B.N. - Hepatitis A shifting epidemiology in South-East Asia and China. Vaccine, 18 (suppl. 1): S61-S64, 2000.

2.BIZIAGOS, E.; PASSAGOT, J.; CRANCE, J.M. \& DELOINCE, R. - Long-term survival of hepatitis A virus and poliovirus type 1 in mineral water. Appl. environ. Microbiol., 54: $2705-2710,1988$.

3.DAY, C.; CUMMING, H. \& WALKER, J. - Enterovirus-specific IgM in the diagnosis of meningitis. J. Infect., 19: 219-228, 1989.

4.EHRNST, A. \& ERIKSSON, M. - Epidemiological features of type 22 echovirus infection. Scand. J. infect. Dis., 25: 275-281, 1993.

5.FATHALLA, S.E.; AL-JAMA, A.A.; AL-SHEIKH, I.H. \& ISLAM, S.I. - Seroprevalence of hepatitis virus markers in Eastern Saudi Arabia. Saudi med. J., 21: 945-949, 2000 .

6.GAHLINGER, P.M. \& ABRAMSON, J.H. - Computer programs for epidemiologic analysis. Georgia, PEPI, Version 2. Stone Mountain, 1995.

7.GASPAR, A.M.C.; OLIVEIRA, J.M.; SILVA, M.L.P. \& YOSHIDA, C.F.T. - Orally transmitted acute hepatitis in Rio de Janeiro, Brazil (1989-1995). In: BUISSON, Y; COURSAGET, P. \& KANE, M., ed. Enterically-transmitted hepatitis viruses. Jouélès-Tours, La Simarre, 1996. p. 99-100.

8.HADLER, S.C. - Global impact of hepatitis A virus infection changing patterns. In: HOLLINGER, B.N.; LEMON, S.M. \& MARGOLIS, H.S., ed. Viral hepatitis and liver disease. Baltimore, Williams \& Wilkins, 1991. p. 14-20.

9.LEONI, E.; BEVINI, C.; DEGLI ESPOSTI, S. \& GRAZIANO, A. - An outbreak of intrafamiliar hepatitis A associated with clam consumption: epidemic transmission to a school community. Europ. J. Epidem., 14: 187-192, 1998. 
VILLAR. L.M.; DE PAULA, V.S. \& GASPAR, A.M.C. - Seasonal variation of hepatitis A virus infection in the city of Rio de Janeiro, Brazil. Rev. Inst. Med. trop. S. Paulo, 44(5):289-292, 2002.

10. McCAUSTLAND, K.A.; BOND, W.W.; BRADLEY, D.W.; EBERT, J.W. \& MAYNARD, J.E. - Survival of hepatitis A virus in feces and after drying and storage for 1 month. J. clin. Microbiol., 16: 957-958, 1982.

11. MIOSSEC, L.; LE GUYADER, F.; HAUGARREAU, L.; COMPS, M.A. \& POMMEPUY, M. - Possible relationship between a winter epidemic of acute gastroenteritis in France and viral contamination of shellfish. J. Shellfish Res., 17: 1661-1664, 1998.

12. PAPAEVANGELOU, G.; ROUMELIOTOU-KARAYANNIS, A. \& CONTOYANNIS, P. - Changing epidemiological characteristics of acute viral hepatitis in Greece. Infection, 10: $1-4,1982$.

13. PHILLIPS, C.A.; ARONSON, M.D.; TOMKOW, J. \& PHILIPS, M.E. - Enterovirus in Vermont, 1969-1978: an important cause of illness throughout the year. J. infect. Dis., 141: 162-164, 1980.

14. SOBSEY, M.D.; SHILEDS, P.A.; HAUCHMAN, F.S. et al. - Survival and persistence of hepatitis A virus in environmental samples. In: ZUCKERMAN, A.J., ed. Viral hepatitis and liver disease. New York, Alan R. Liss, 1988. p. 121- 124.
15. TANAKA, J. - Hepatitis A shifting epidemiology in Latin America. Vaccine, 18 (suppl. 1): S57-S60, 2000.

16. TUFENKEJI, H. - Hepatitis A shifting epidemiology in Middle East and Africa. Vaccine, 18 (suppl. 1): S65-S67, 2000.

17. VITRAL, C.L.; YOSHIDA, C.F.T.; LEMOS, E.R.S.; TEIXEIRA, C.S. \& GASPAR A.M.C. - Age-specific prevalence of antibodies to hepatitis A in children and adolescents from Rio de Janeiro, Brazil, 1978 and 1995. Relationship of prevalence to environmental factors. Mem. Inst. Oswaldo Cruz, 93: 1-5, 1998.

18. YAO, G. - Clinical spectrum and natural history of viral hepatitis A in a 1988 Shangai epidemic. In: HOLLINGER, B.N.; LEMON, S.M. \& MARGOLIS, H.S., ed. Viral hepatitis and liver disease. Baltimore, Williams \& Wilkins, 1991. p 76-78.

Received: 27 March 2002

Accepted: 03 July 2002 